\title{
A TOOLKIT FOR DETECTING AND ELIMINATING THE BARRIERS THAT PEOPLE WITH DISABILITIES FACE IN THE BUILT ENVIRONMENT: THE CASE OF SLOVENIA, EUROPE
}

\author{
Boštjan KERBLER*
}

Received: 19.04.2012; Final Text: 17.07.2012

Keywords: disability; people with disabilities; built environment; built environment barriers; barrier-free access; toolkit.
* Urban Planning Institute of the Republic of Slovenia, Ljubljana, SLOVENIA.

\section{INTRODUCTION}

Accessibility is defined as the opportunity for an individual at any given location to take part in a particular activity or set of activities (Jones, 1981). It encompasses a broad range of areas such as housing, employment and training, the justice system and leisure services; first of all, however, accessibility means that everybody should have access to the built environment. An accessible built environment means providing buildings and places that are designed and managed to be safe, healthy, convenient and enjoyable for use by all members of society, which means that each "person will be able to seek employment, receive education and training" (Ambrose et al. 2003, 3). Therefore, an accessible built environment is key for a society based on equal rights, providing citizens with autonomy and the means to pursue an active social and economic life.

The built environment, especially in cities, creates obstacles and barriers. These are both permanent and temporary for all people, but particularly for those with a disability. Those whose lives are circumscribed by an inaccessible built environment are primarily people with a physical disability (permanent or temporary), a visual or hearing impairment or a learning disability. The World Health Organisation (2011) estimates that people with disabilities account for one billion of the total world population. In Europe, one in five to six people has a disability that ranges from mild to severe, totalling around 80 million that are often prevented from fully taking part in society and the economy because of the inaccessible built environment. Given the rapidly increasing populations of older people, especially those over 80 , the percentage of people with disabilities might be expected to grow in the future. In spite of these relatively large numbers, people with disabilities regrettably face limited access to jobs, goods and services such as education, healthcare, transport, housing, technologies and information, are poorer than other citizens and are more often socially excluded. Around $80 \%$ of respondents to the public 
consultation (citizens and organisations) for a new disability strategy of the European Union (European Commission, 2010) agreed or strongly agreed that people with disabilities face discrimination in their everyday activities, and $95 \%$ of respondents to the same public consultation said that lack of access to the built environment was an important or very important issue in discrimination.

This paper therefore presents a toolkit created by the author that facilitates easier detection of barriers in the built environment and the prevention of new ones. The toolkit is a result of a study conducted from 2009 to 2011 by the Urban Planning Institute of the Republic of Slovenia, in collaboration with the Institute for Social Protection of the Republic of Slovenia. First, the article lays out the framework of the study. It continues by describing the research methodology. The second part presents the results, followed by a discussion that argues and provides supporting evidence that the toolkit is an instrument that allows an accessible built environment and thereby ensures equal rights in society for people with disabilities. The conclusion presents the broader significance of the toolkit for the community, contains recommendations for its implementation and highlights its capacity for international transferability.

\section{RESEARCH FRAMEWORK}

An accessible built environment for people with disabilities and facilitation of their active participation in society presents a major challenge worldwide. Due to a growing awareness of these issues, there has been a noticeable increase in the number of researchers and other experts engaged in this field. The scholarly literature includes various subtopics related to planning and designing the built environment for the needs of people with disabilities. In responding to the building needs of people with disabilities, some authors stress the notion of "inclusive design" (e.g., Imrie and Hall, 2001), or "design for all" (e.g., Goodall and Pottinger, 2010), also referred to as "universal design" (e.g., Mace, 1998; Erk1lıç, 2011), which means user-friendly planning and provides smart and functional solutions that can serve the broadest circle of users with the least difficulty. Concrete examples of such design concepts are "life-time homes" (see, e.g., Milner and Madigan, 2004), which are living spaces that allow for functional adaptations of the living environment and furniture to the users' needs throughout their lives, whereby the costs of adaptation are minimal. Other authors have focused on technological innovations intended to make the lives of people with disabilities easier and improve their quality of life. One such electronic innovation is "assistive technologies". According to Dewsbury et al. (2004), this involves any kind of device or system that enables individuals to carry out a task that they would otherwise be unable to perform, and provides users with more effective supervision of the built environment with the least possible physical exertion. The development of modern information and communication technologies offers new opportunities and solutions for making the built environment more accessible. This involves the concept of "ambient intelligence" or a "smart environment", which combines computer and advanced network and assistive technologies, creating conditions that give people with disabilities the highest level of functional autonomy and independence in the built environment (see, e.g., Remagnino and Shapiro 2007). Irrespective of various approaches, the authors state that planning and designing the built 
environment must always take into account the regulations and standards prescribed for guaranteeing barrier-free access for people with disabilities.

The need to create and achieve a barrier-free built environment has not been solely a scholarly discourse. The capacity to access and fully participate in society is a human right. As such, accessibility is also an important political issue because the realisation of human rights falls first and foremost within the political sphere. Many political declarations, strategies, programmes, laws, regulations, technical standards and guidelines have therefore been adopted to eliminate all forms of discrimination by removing various barriers and restrictions in the built environment. Among these, the 1981 declaration of the first International Year of Disabled Persons stands out as one of the major turning points in raising global awareness and mobilisation of international action. A major outcome of this was the formulation of the "World Programme of Action Concerning Disabled Persons" adopted by the United Nations General Assembly in 1982, with concrete recommendations on accessibility to the built environment (United Nations, 1982). Subsequently, a first manual titled Designing with Care was published to provide technical and architectural guidelines (Hansen, 1981). The next important milestone at the international level was in 1993, when the United Nations General Assembly adopted its "Standard Rules on the Equalization of Opportunities for Persons with Disabilities", which stated that countries should initiate measures to remove barriers to participation in the physical environment such as housing, buildings, public transport services and other means of transportation, and streets and other outdoor environments, and also that accessibility requirements should be included in designing and building the physical environment from the beginning of the design process (United Nations, 1993). In 2006 the General Assembly adopted its "Convention on the Rights of the Disabled", a historic document that presents the first legally binding United Nations document on disability and barrier-free access. One of the eight guiding principles that underlie the convention is also accessibility to the physical environment, enabling people with disabilities to fully exploit and enjoy human rights and basic freedoms (United Nations, 2006).

Since the first International Year of Disabled Persons in 1981, many initiatives have been carried out in the European Union. The resolution "The Social Integration of Disabled People - A Framework for the Development of Community Action", adopted by the Commission of the European Communities in 1981, proposed an integrated programme supporting local projects with the aim of removing barriers to the full participation of people with disabilities in active life, including access to buildings and facilities. Furthermore, the commission announced its intention to raise a number of policy initiatives. The two subsequent Helios programmes were created in the late 1980s and early 1990s. Projects carried out under these programmes sought to promote an independent way of life, covering access to public buildings and facilities (Geyer, 2002; Ambrose, 2003). The next major step towards barrier-free access was the adoption of three documents on equal opportunity for people with disabilities: the "Communication of the Commission on Equality of Opportunity for People with Disabilities" from 1996 (Commission of the European Communities, 1996), the "Resolution of the Council and of the Representatives of the Governments of the Member States on Equality of Opportunity for People with Disabilities" from 1997 (Council of the European Union, 1997) and the directive 'Towards a Barrier Free Europe 
for People with Disabilities' from 2000. One of the directive's provisions was that the commission will support projects that incorporate accessibility requirements, and approve standards or recognise best practice in design and construction, as well as new ways to promote universal design in accessibility (Commission of the European Communities, 2000). Based on the achievements of the 2003 European Year of People with Disabilities, the European Commission introduced a multiannual action plan to facilitate implementation of specific measures to enhance the economic and social integration of people with disabilities. A particularly important issue of the action plan addressed building design and construction in compliance with the principle of universal design as a means of guaranteeing people with disabilities effective access to the built environment and, therefore, full integration into the economy and society (Commission of the European Communities, 2003). The new European Disability Strategy 2010-2020, launched by European Commission in November 2010, focuses on accessibility:

"Accessibility is a precondition for participation in society and in the economy, but the European Union still has a long way to go in achieving this. The Commission proposes to use legislative and other instruments, such as standardisation, to optimise the accessibility of the built environment, transport and ICT." (European Commission, 2010, 5)

"A very effective option for achieving this is to develop standards for accessible goods and services at the European level and to use public procurement to promote accessible public buildings", said Viviane Reding, vice-president and EU commissioner for justice, fundamental rights and citizenship. According to the strategy, the commission will consider proposing a European Accessibility Act in 2012 or 2013. This will set out a general accessibility framework in relation to goods, services and public infrastructure using various instruments such as standardisation, public procurement or state aid rules, as well as new technologies such as assistive devices.

The new EU strategy is certainly most welcome. However, its continued focus on accessibility shows that, despite longstanding commitments to achieving barrier-free access, the right of people with disabilities to an accessible built environment is still not ensured. Guaranteeing accessibility is an area where more progress still needs be made. Laws have been adopted, strategic documents formulated and international conventions ratified, but the level of practical implementation has remained low. Regulations and standards, where these exist, are not properly and consistently implemented and enforced. Consequently, there has not been much improvement at the levels concerned. In some EU countries, little has changed for the past thirty years, since the first International Year of Disabled Persons. This was precisely the main conclusion of the research conducted within the Sixth Framework programme, entitled "Free Movements and Equal Opportunities for All" (known as LivingAll), which included eleven partners from seven European countries (Austria, Belgium, Italy, Norway, Slovenia (the author of this article participated), Spain and the UK) (Garcés et al., 2007). One of the major findings of the research was that, in the majority of the countries covered by the survey, the resolutions ratified and legislation adopted are inadequately or inefficiently implemented. It was observed that there remains a huge gap between formal commitment and practical implementation. This finding laid the basis for the key research recommendation; namely, an urgent need to develop and propose methodologies and design efficient 
mechanisms for implementing policies to guarantee barrier-free access for people with disabilities. In collaboration with the Institute for Social Protection of the Republic of Slovenia, the Urban Planning Institute of the Republic of Slovenia conducted a new and more focused empirical survey in Slovenia from 2008 to 2009. The research yielded two important findings. First, people with disabilities listed numerous built-environment barriers that they continue to experience daily in all spheres of life covered by the survey (healthcare, social care, education, employment, public services, transport, cultural activities and recreational facilities, including tourism). Second, the majority of respondents pointed out noncompliance with regulations and building standards as one of the greatest problems that hinder achievement of a barrier-free built environment. In addition to these findings, many respondents made a very important suggestion towards the removal of existing barriers. They proposed conducting a detailed field investigation to identify and systematically register all existing barriers in the major public buildings and public facilities and present the findings to the various bodies or institutions responsible for the specific barrier, with a demand that the barriers be removed promptly (Sendi and Kerbler, 2009). The research team accepted this proposal as an important starting point for developing a mechanism to ensure greater efficiency in realizing the rights of people with disabilities to an accessible built environment and introducing fundamental changes into existing structures of responsibility and accountability. This idea was therefore the focus of the research that followed from 2009 to 2011. Because the research raised sensitive ethical questions related to human beings and personal data, the project was approved only with the assurance that these questions were adequately taken into consideration.

The major issue presented in this article is the mechanism that was developed as the final result of the research on facilitating greater effectiveness in realizing the rights of people with disabilities to barrier-free access to the built environment.

\section{RESEARCH METHODOLOGY}

To create the toolkit, data were gathered by inventorying barriers in the built environment. Focus was placed on the accessibility of public facilities because guaranteeing full accessibility to all public facilities is one of the major goals of "Strategy Accessible Slovenia", one of the principle government documents. Because it was not possible to examine the accessibility of all facilities during the course of the research project, the focus was placed on the major towns in the twelve regions of the country, and two important public facilities were analyzed in each one. The first was the municipal administration building, which was chosen as a constant, and the second facility related to the one of the various spheres of life, such as healthcare, social care, education, employment, public services, transport, cultural activities and accessibility of recreational facilities. The local administration facility was chosen as one of the buildings that every individual is likely to visit at least once in their lifetime (for registering residence, personal documents, regulating property rights, etc.). The investigation of the same kind of facility during the fieldwork also made possible a comparative analysis of the various levels of accessibility. Twenty-six public facilities were evaluated in the field research. The accessibility of public facilities was examined for three types of disability: people with impaired mobility, the blind and partially sighted, and the 
Figure 1. Persons with disabilities that participated in evaluating the accessibility of public facilities: physically impaired (Besim, Matej, Mija, Tea), blind (Marko and Toni) deaf / hard of hearing (Srečo, Simon, Barbara) (photo: Nina Goršič, Biba Tominc).
Figure 2. Preparation of the fieldwork with the persons with disabilities, or "mentors" (photo: Nina Goršič).
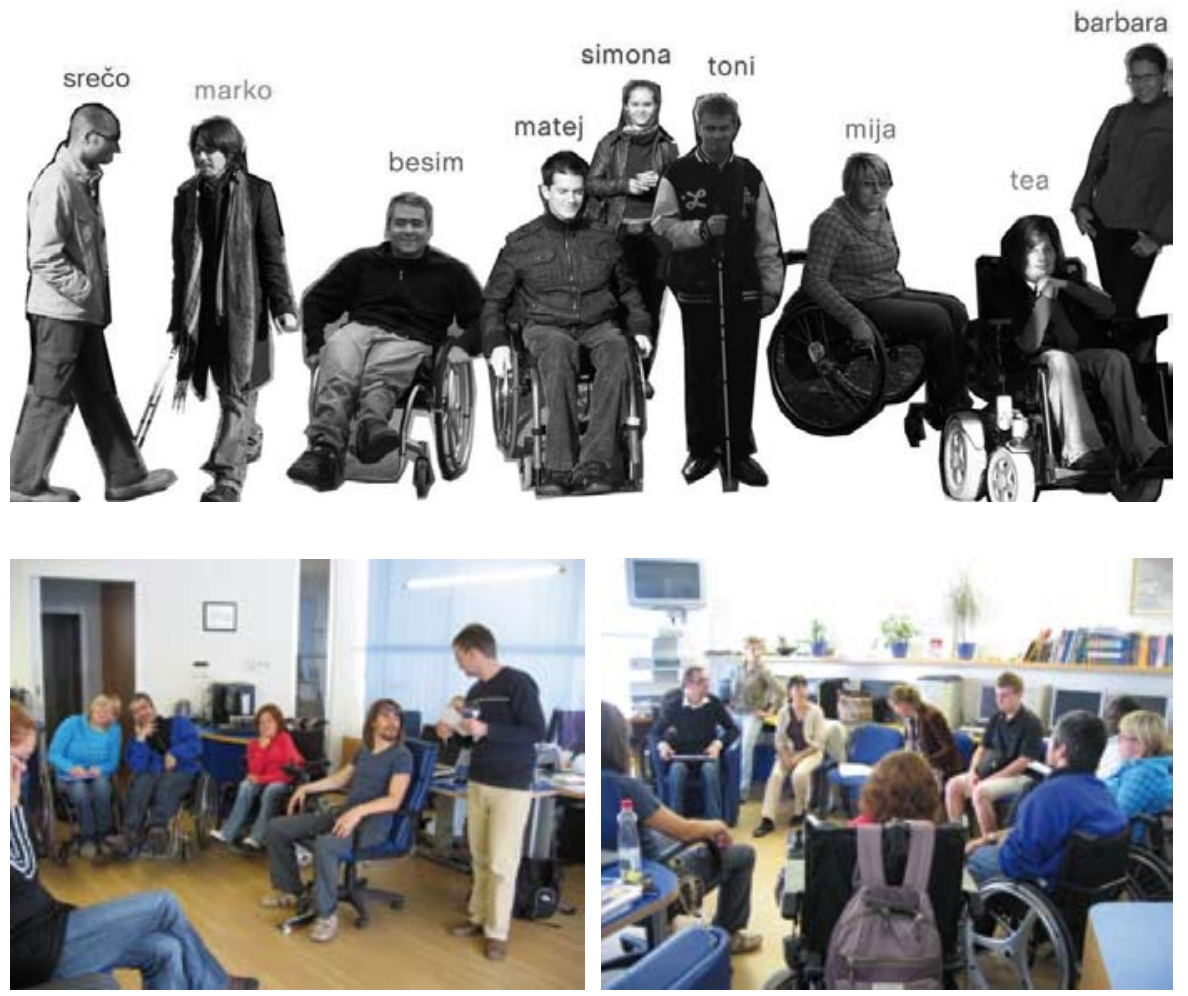

deaf and hard of hearing. In order to ensure the most accurate assessment of accessibility of facilities, it was decided to use a "bottom-up" approach. Therefore, people with disabilities in all three categories physically participated in the fieldwork. Altogether, eight disabled people were involved in the evaluations: four of them were physically impaired, and four were sensory impaired (two blind and two deaf / hard of hearing). All persons with disabilities that participated in evaluating the accessibility of public facilities are presented on the Figure 1.

Assessment of each of the selected public facilities was carried out by a group of six people ("assessors"), which consisted of:

- Three researchers (non-disabled) that participated in the project; these were experts in urban planning and architecture;

- Three people with disabilities, one physically impaired person (in a wheelchair), one deaf / hard of hearing person, and one blind person.

Before carrying out the assessment of public facilities, all people with disabilities participating in the field inventory of barriers were given detailed information about the intended manner of work, methods and workflow (Figure 2), and two field tests were also carried out before the assessment started. Because we wanted the most commonplace situation, the field investigation at the selected facilities was unannounced.

An "inspection list" was designed for the field investigation and evaluating accessibility. It was prepared based on a preliminary detailed review of current legislation and all relevant regulations and standards concerning barrier-free access to the built environment. It covers all major aspects of accessibility of each individual facility, starting from the exterior space 
(parking spaces, entrance paths, gradients, etc.), followed by the entrance (doors, thresholds, etc.), hall, information desk, staircase/lift, corridors, public offices and public toilets in the facility. The accessibility assessment also included details such as door width, floor coverings, height of door handles, public notice lettering, colouring, lighting, sound systems, tactile markings, induction coils/loops and other assistive devices included in the built environment. Because the inspection list contains more than 200 questions, the field investigation of a facility required an average of 3 to 4 hours of intense time. Examples of questions on the inspection list are:

- Are at least $5 \%$ of parking spaces provided for persons with disabilities?

- Is the width of the access path at least $900 \mathrm{~mm}$ ?

- Is there an unobstructed flat area in front of the main door, which means that there is enough space for access for persons in wheelchairs?

- Is the entrance clearly marked with floor marks in a tactile form and with a sign adapted for the visually impaired?

- Does the information desk allow independent use by persons with hearing impairment (does it have a built-in induction loop/coil)?

- Is the lighting designed in a manner that the reflection of the light on the glass surfaces of the information desk window is as little as possible, which allows persons with a hearing impairment to read lips?

- Is the time for opening the sliding door on the lift long enough for smooth passage of a person in a wheelchair?

- Is the switchboard at the entrance in at least one of the elevators fitted with acoustically distinctive sounds (for the blind)?

- Does the colour of the signs contrast with the background (black text on a white, yellow or other light background)?

- Etc.

In addition to the inspection list, other standard technical devices were used (a tape measure, gradient gauge, and camera). All information gathered in the fieldwork was recorded on the inspection list, and all other observations, thoughts and questions in a field book.

\section{RESULTS AND DISCUSSION}

The results of the field investigation confirmed the main findings of the survey that was conducted in 2008-2009. None of the public facilities analyzed were completely free of barriers.

For physically impaired persons, the most common barriers were identified as a lack of parking spaces for people for disabilities and their unauthorized occupancy, high curbs and sidewalks that are not reduced to ground level at road intersections, inadequate road infrastructure (such as paved areas, grates for drainage, sewer covers, etc.), stairs, missing ramps or ramps that are too steep or too long and do not require safe access, heavy entrance doors and other heavy doors in the buildings, thresholds that are too high, elevators often out of order, lack of handles or rails, narrow doors and narrow passageways/corridors, information 
desks and other equipment too high (e.g., parking meters, switches, information boards, computer information points, ticket machines, etc.), and inadequately equipped or inaccessible toilets for people in wheelchairs or their absence (Figure 3).

For sensory-impaired persons, inadequate information systems are the greatest hindrance (Figure 4). Blind and partially sighted people drew attentiion to unreadable inscriptions, the absence of labels (e.g., tactile markings; contrasting markings on windows, stairs and dangerous edges; signage in Braille, etc.), no acoustic signals (e.g., verbal warnings and announcements, etc.), poor lighting of rooms, drain gratings with gaps so wide that blind persons' sticks can become stuck in them, barriers on walking paths (such as advertising boards, flower pots, parked bicycles, etc.). For hearing-impaired persons, particularly serious barriers are the lack or absence of interpreters, lack of lighting signals (such as lighting displays), poor sound systems and an absence of induction coils/loops, and tinted windows or improperly installed information panels (e.g., reflection of light on the glass surfaces is too high on the information desk window, which does not allow lip reading).

All information gathered in the fieldwork was later entered into a specially designed data-processing system on a computer. The result of these efforts is the toolkit presented below.

Figure 3. Barriers faced by physically impaired persons in access to public facilities and inside them (photo: Nina Goršič, Sabina Mujkić, Matej Nikšič, Biba Tominc).

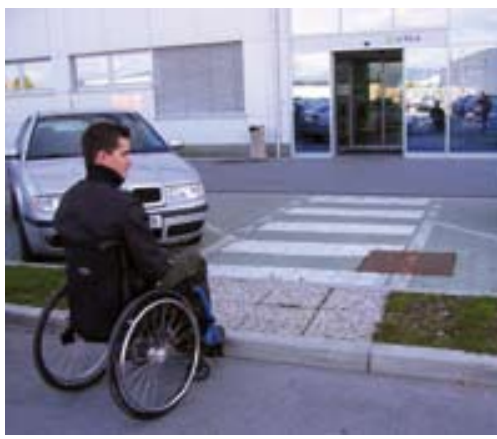

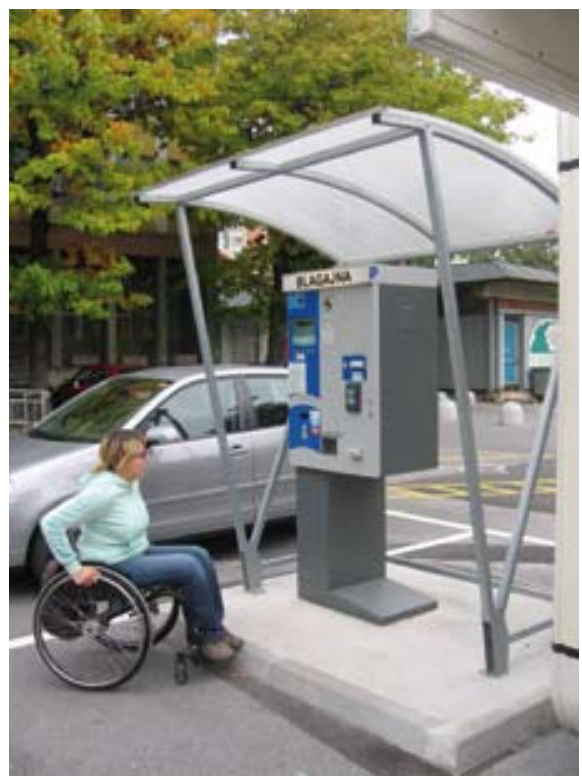
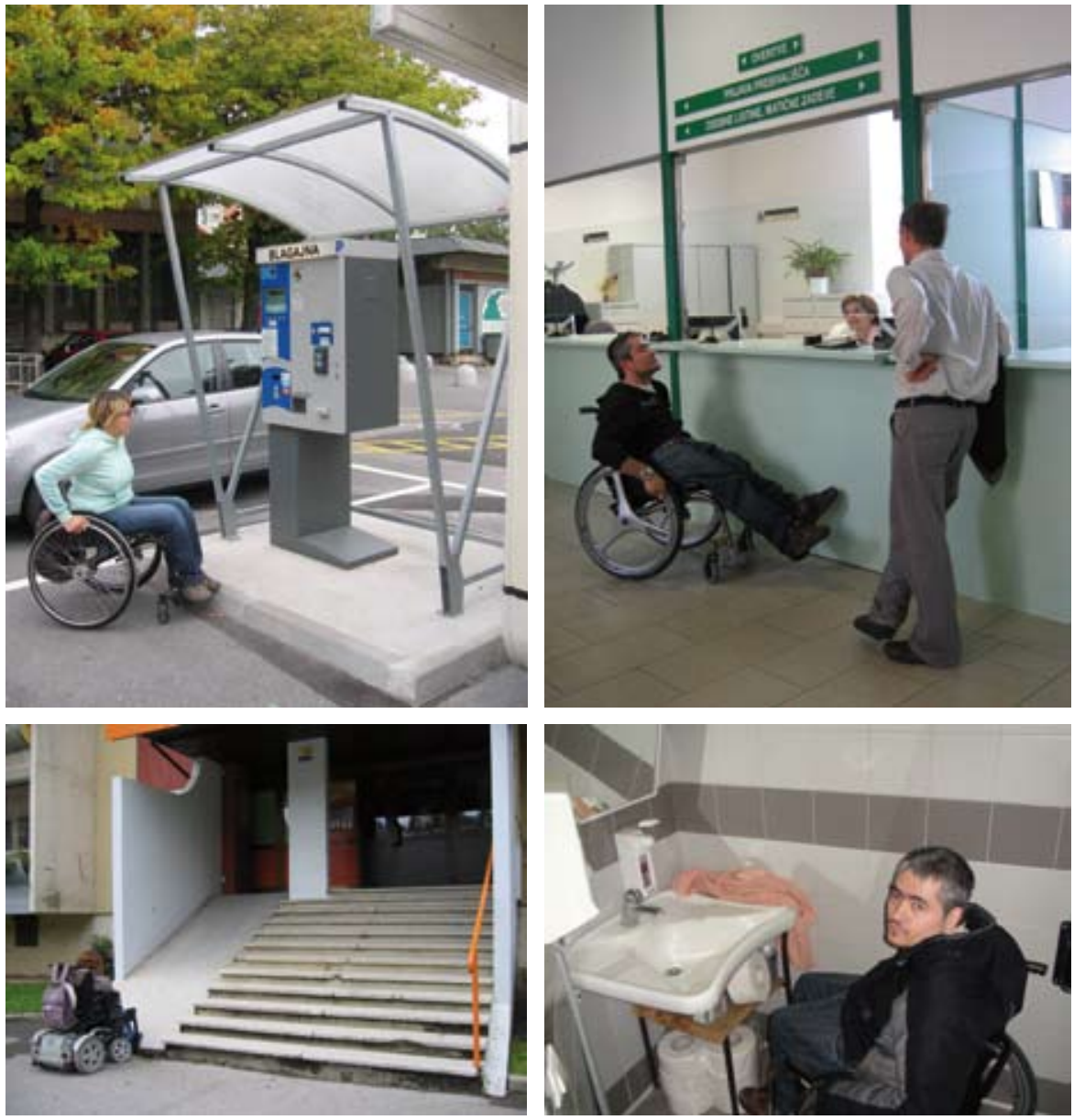
Figure 4. Barriers faced by sensory-impaired persons in access to public facilities and inside them (photo: Nina Goršič, Sabina Mujkić, Matej Nikšič, Biba Tominc).
The toolkit that was developed is clearly a significant step towards practically realising various commitments concerning accessibility of the built environment for people with disabilities. Over the past decades, these commitments have remained on paper without effective implementation. It is argued below that it is an appropriate mechanism for more easily detecting barriers in the built environment and preventing the occurrence of new ones because it enables: (a) Unlimited and user-friendly access to information on accessibility; (b) Public participation for providing accessibility; (c) Permanent monitoring and effective action for eliminating barriers in the built environment.

\section{Unlimited and User-friendly Access to Information on Accessibility}

The internet has become a fundamental communication tool for access to information and freedom of expression. Therefore, all information gathered during the fieldwork was placed on the internet (by creating a special website) to provide unlimited and user-friendly access to information on the accessibility of facilities in public use. As recognised by scholars, policymakers and the general public, the internet has tremendous potential to improve everyday life, especially for those on the margins of society, and to achieve greater social equity and empowerment (Mehra et al., 2004). The
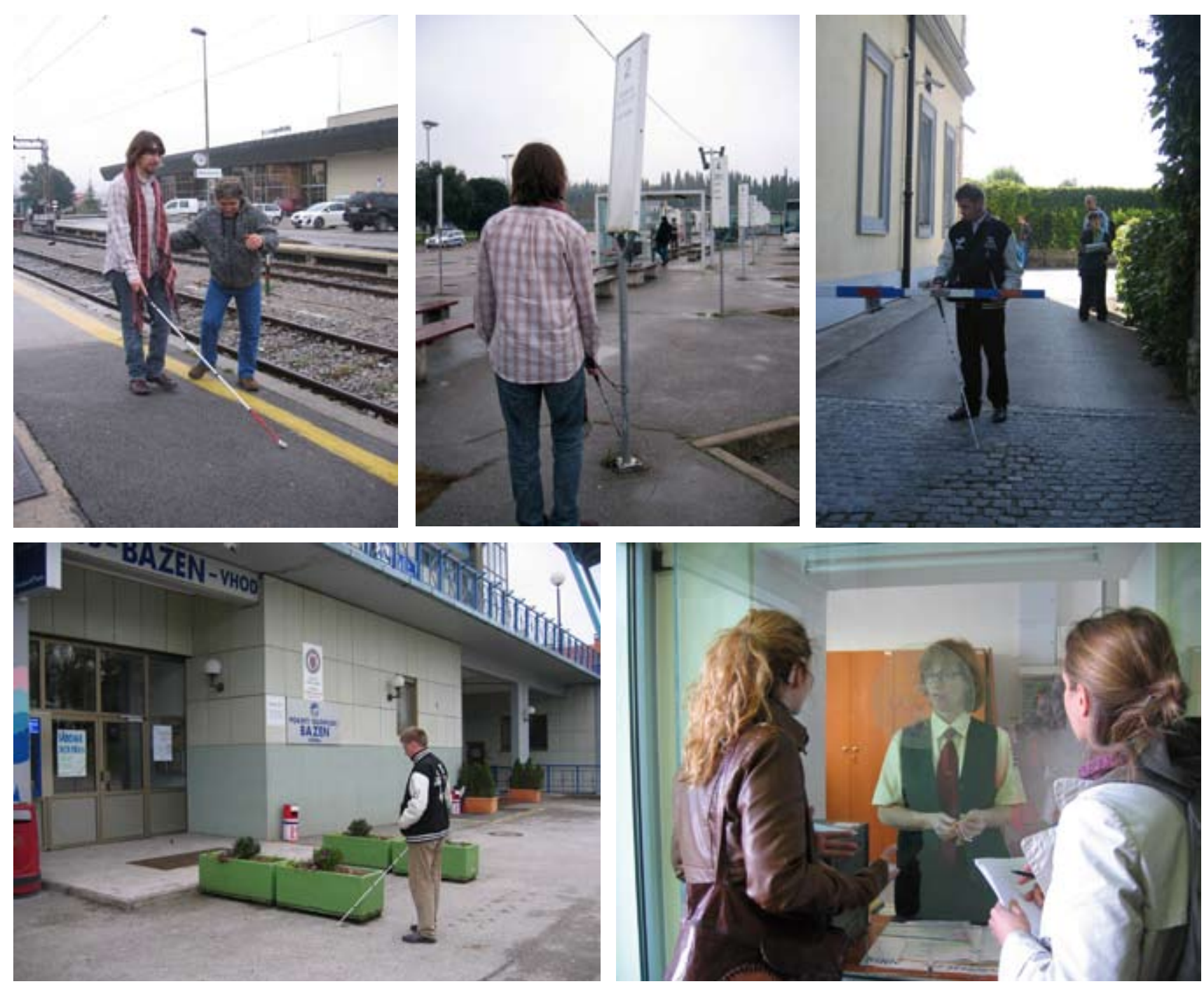
internet can therefore also transform the personal experiences of people with disabilities by creating a playing field for empowerment with access to information, connections and a platform for change. The only condition is that the internet be readily accessible. An accessible website is "one that has been designed so that people with functional limitations (e.g. visual, motor, cognitive and auditory impairments) and situational limitations (e.g. those using alternative web-access equipment) can freely access the content of the site" (Parkinson and Olphert, 2010, 166-7). A similar description states that an accessible website should be "'perceivable, operable and understandable', without barriers, for all people" (Thatcher et al., 2003, 8). More specifically, this means that people with disabilities can perceive, understand, navigate and interact with the internet and that they can contribute to it. Internet accessibility is about design that allows more people to use a website effectively in various situations. When websites are correctly designed, developed and edited, all users can have equal access to information and functionality (Henry, 2006). However, according to Coeffic et al. (2010) the internet is still inaccessible in many respects to people with disabilities because internet designers do not always meet the criteria for preparing websites suitable for use by people with various disabilities.

"Many web sites are designed based on the individual designer's preferences, abilities and environment. A large percentage of web site designers are without disabilities, experienced with computers and operating with the latest technologies. Thus, all too often, that is the user profile they tend to design for." (Henry, 2006, 11)

Even when a specific user analysis is conducted, the range of users considered is often too narrow. Primarily because of a simple lack of awareness, designers tend not to include people with disabilities and people operating in more unusual environments in their user analysis (Henry, 2006).

To remedy these lacks in accessibility, the latest available material and information and communication software technologies were taken into account in preparing the website while seeking the most adequate solutions. A "user-centred design approach" followed, considering usability goals and users' characteristics, environment, tasks and workflow in designing the interface. People with disabilities were included in order to evaluate the accessibility of the website and any problems or deficiencies that might arise. Therefore, the website enables full participation of people with auditory, physical and visual limitations because a special menu (called "Blind") was created in which all the information is also adjusted for the blind and partially sighted. In the menu, all the information (including the interpretation of the images) is in text format (HTML format), making it possible for the visually impaired to "read" using any of the software tools for screen reading ("screen readers"). Screen readers allow the user to listen to information from the display using a speech synthesizer or to read with their fingers on a Braille keyboard. In creating such menus it is important that the main page of the website contain an index of all content that the user can access by clicking on it (Figure 5), and at the end of each subpage there should be a "back to menu" button that the user can click to return to the main page with the table of contents. Concerning people with this type of disability, the website also makes it possible to adjust the font size and colours (Figure 6).

Generally, the website is simplified and very easy to use. All information about the accessibility of facilities is gathered in a special menu called 
Figure 5. The website is adjusted for the blind and partially sighted; the figure shows the main page of the special "Blind" menu.
Figure 6. The website makes it possible to adjust the font size and colours, which is important for the partially sighted.
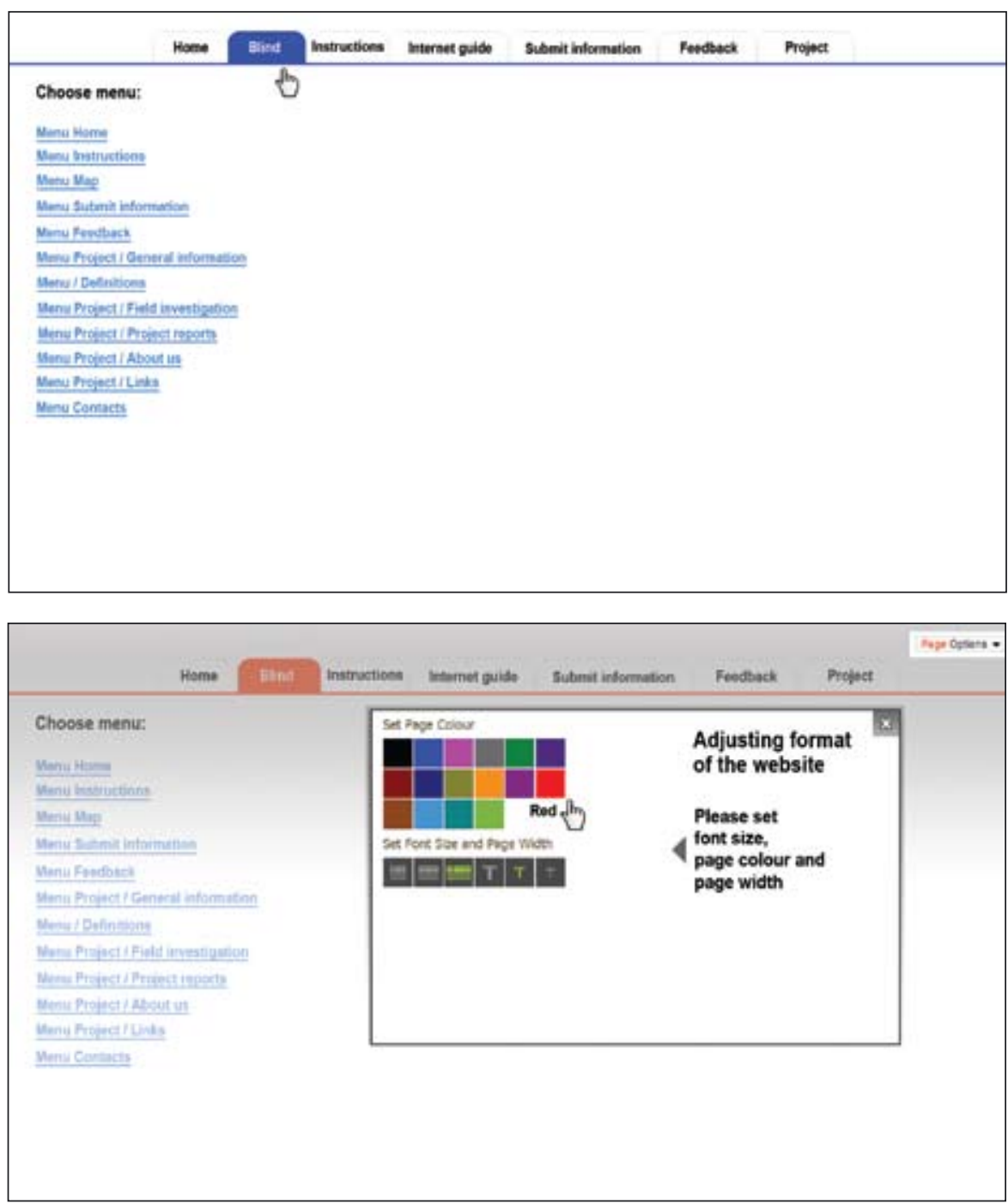

the "internet guide". There are two ways to search for information about the accessibility of facilities in public use through this guide; that is, by different places (Figure 7) or by activities, such as transport, education, healthcare, social care, employment, public services, public administration, culture, sport and recreation, catering and tourism (Figure 8). The website was also created as a geographical information system. It shows the specific location of a particular facility (satellite image or topographic map), its orientation in space, and a photo of the facility, its full address and information on when the field investigation was carried out (Figure 9). Therefore, users can also receive information about the accessibility of a specific facility by clicking on the location on the map.

The information about the accessibility of a particular facility covers all major aspects of accessibility for a particular disability, just as in the "inspection" list: parking spaces, accessibility to the facility (entrance paths), gradients on the entrance paths, entrance to the facility, gradients on the entrance to the facility, entrance hall, information desk and facilities for dealing with customers, restrooms, interior paths (corridors etc.), gradients inside the facility (staircase, lift, etc.), signs, and other features. By clicking on one of the major aspects ("facility element"), more 
Figure 7. The website's search engine for information about the accessibility of facilities in public use by place.

Figure 8. The website's search engine for information about the accessibility of facilities in public use by activity.

Figure 9. The website includes a map by which a particular facility can be located in space.
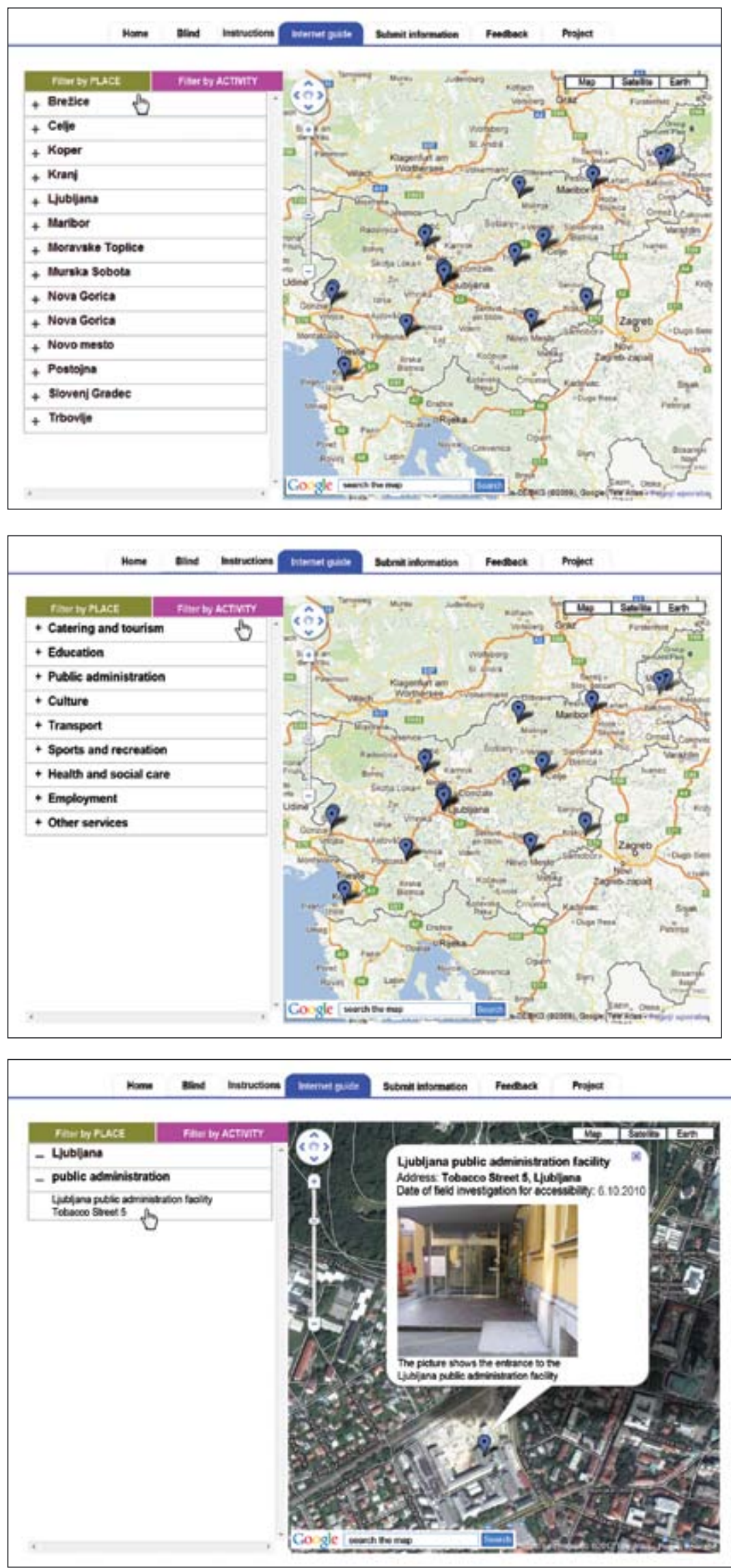
Figure 10. Information about the accessibility of a particular facility by "facility elements" and by particular disability.
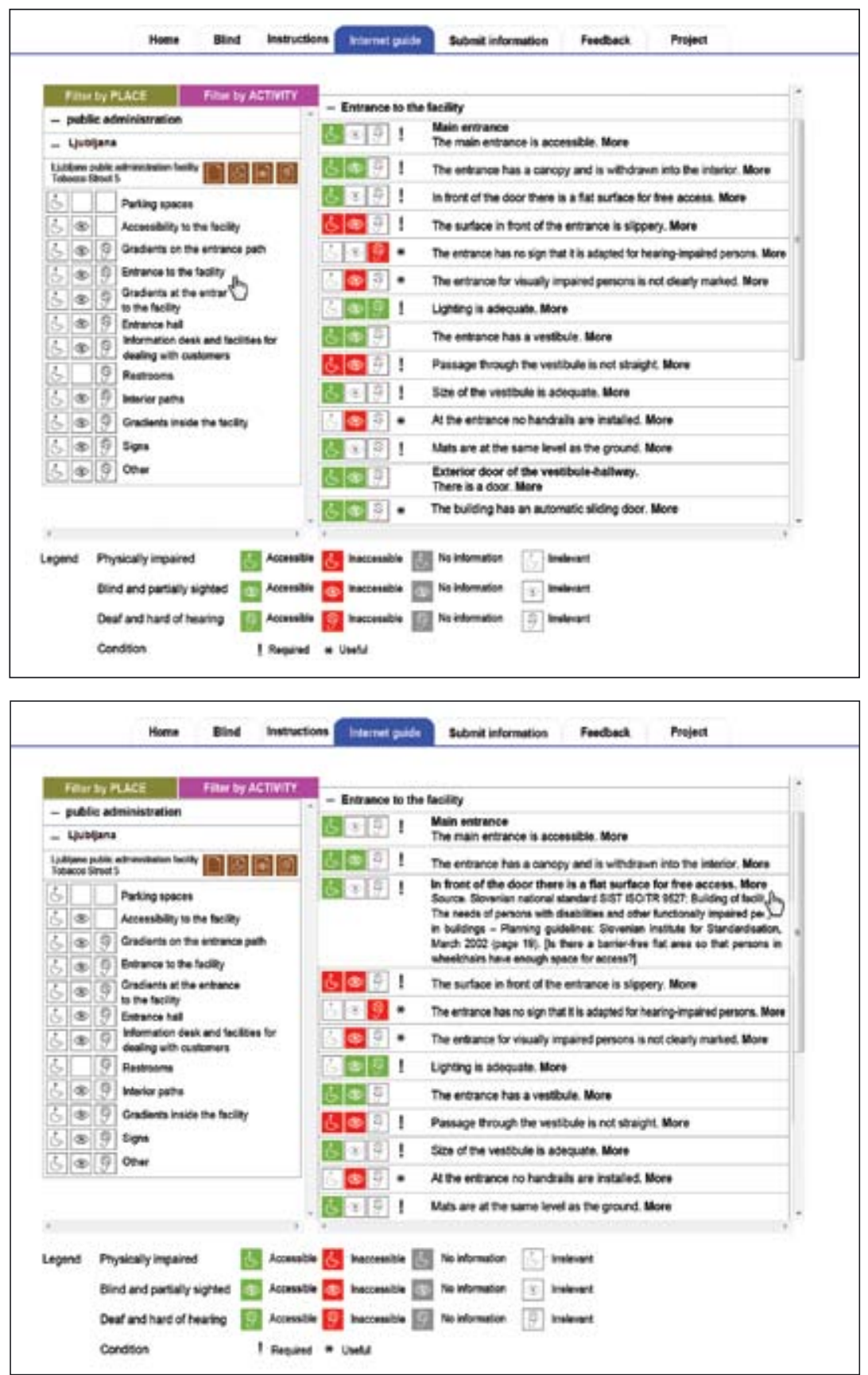

detailed information about the accessibility is displayed (Figure 10). The accessibility of a particular "element" in the facility for a particular form of disability is shown by the colour of the standard (international) symbol representing that disability (e.g., a wheelchair for people with physical limitations, an eye for the visually impaired and an ear for people with auditory impairments); for example, a green symbol means "accessible", red "inaccessible", gray "no information" and no colour "irrelevant for the particular disability". By clicking on one of the brown icons (in Figure $\mathbf{1 0}$ these icons are placed on the left side, next to the name and address of the public facility), information about the accessibility may be also printed out, specifically for all disabilities (first brown icon) or for a particular disability 
(the other three icons), which means that the user can select only the information that relates to a particular disability.

Finally, the website is adjusted not only for people with disabilities, but also for owners or managers of facilities as well as for planners, other professionals and the general public. By clicking on the word "more" next to the accessibility information (Figure 10), information on the sources (laws, regulations and standards) on which the accessibility assessment criteria are based open (Figure 11). Next to the source there is also a question created on the basis of the source text and used in the "inspection" list. This offers stakeholders comprehensive insight into compliance with laws and regulations, which can serve as a means of educating or raising awareness about the various barriers encountered by people with disabilities and as an argument for strengthening efforts to ensure the rights of people with disabilities to an accessible built environment.

\section{Public Participation for Providing Accessibility}

To facilitate active participation of people with disabilities and also of the general public, the website also includes a web forum that enables the identification of barriers anytime and anywhere in the built environment. As such, the web forum offers an opportunity for gathering relevant information about the accessibility of the built environment and barriers that people observe in their environment with the help of public participation. According to the Calouste Gulbenkian Foundation $(1973,4)$ public participation is "a democratic process of engaging people in thinking, deciding, planning, and playing an active part in the development and operation of services that affect their lives". Therefore, participatory development is important for entrusting people with the responsibility to shape their own future. By participating, people affect the success through their involvement. When their voice reaches the desired range of people, their participation attains meaning. If their views are taken into account, it can be argued that the participation was a success. Participation thus increases the strength of the individual and other people because it includes them in the decision-making processes and allows them to actively participate in these processes (Arnstein, 1969).

The International Association for Public Participation $(2011,11)$ defined seven core values of public participation:

- "makes believe that those who are affected by a decision have a right to be involved in the decision-making process;

- "includes the promise that the public's contribution will influence the decision;

- "promotes sustainable decisions by recognizing and communicating the needs and interests of all participants, including decision makers;

- "seeks out and facilitates the involvement of those potentially affected by or interested in a decision;

- "seeks input from participants in designing how they participate;

- "provides participants with the information they need to participate in a meaningful way;

- "communicates to participants how their input affected the decision."

Public participation is therefore part of "people centred" or "human centric" principles. It has been advanced by the humanist movements that have emerged over the last thirty years as part of a "people first" paradigm shift. In this respect, public participation may challenge the concept "that 'big is better' and the logic of centralized hierarchies, advancing alternative concepts of 'more heads are better than one' and arguing that 
Figure 12. The web forum system makes it possible to submit information about barriers in the built environment either by entering the required information directly into the window or by clicking on a particular facility on the location on the map.
Figure 13. All information submitted about the barriers can be also displayed on the screen and/or on the map. public participation can sustain productive and durable change" (Moseti, $2010,1)$. With public participation, which is provided through a web forum, this toolkit therefore enables stakeholders to take the initiative, make steps forward, affect changes and lead development towards achieving the goal; that is, an accessible built environment. Namely, the participation of the general public will gradually lead to the identification of increasingly more barriers and, simultaneously, contribute to updating the information on the website. In addition to identifying existing barriers, the public can also report barriers "in creation"; that is, those that they see being newly constructed. The purpose of this measure is, of course, to prevent the appearance of new barriers. The web forum system offers two ways to supply information about barriers in the built environment: by entering the required information directly into the window that
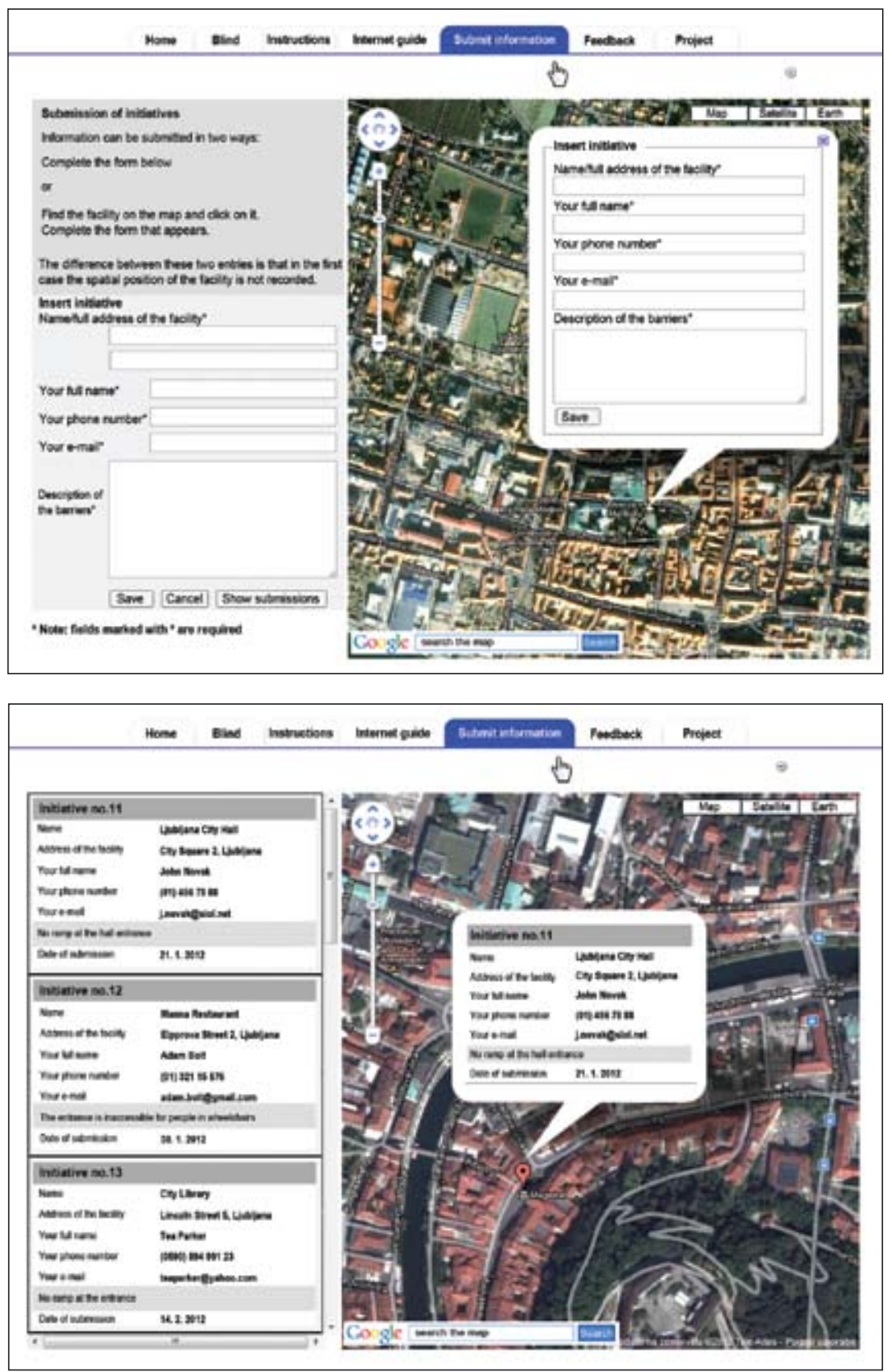
Figure 14. The web forum's "Feedback" menu provides a medium for mutual exchange of information and experiences.

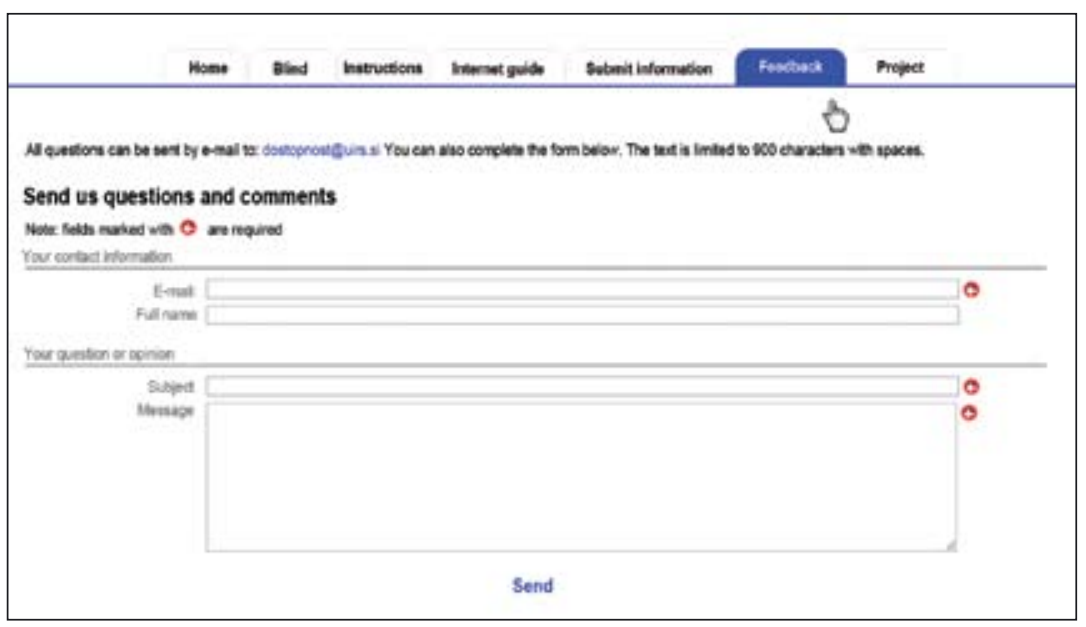

appears when the user clicks "submit information", or by clicking on a particular facility on the location on the map, whereby a window opens into which the relevant information is entered (Figure 12). In either case, the participant is required to supply the following information: name and full address of the facility, name and surname of the initiative provider, phone number and e-mail address of the initiative provider and a brief description of the nature of the barrier being reported. The only difference between the two ways of reporting barriers is in the recognition by the designers of the forum that some participants may not wish to scroll through the map to locate the particular facility they want to address. All information submitted about the barriers can also be displayed on the screen and/or on the map (Figure 13). In addition to reporting barriers, the web forum provides a medium for mutual exchange of information and experiences (Figure 14). In this sense, it is also intended to serve as a communication social network through which people with disabilities and the general public will be encouraged to develop new ideas and suggest improvements to the web forum and the toolkit in general.

The toolkit, as such, represents an important shift from current practice, which is based on the "top-down approach" but, as it turned out, was not effective enough. In contrast, the goal of the alternative "bottom-up approach" ensured by the public participation is to empower people with disabilities to join the organised struggle of all disadvantaged and marginalised groups, and to change our present society into one that is fairer, more truly democratic and more accepting of human differences (Werner, 1995). David Werner also argues that "it is not to force open doors which society has closed against disabled persons. Rather it is to tear down the walls of inequality, to work towards a social order that provides all people with equal respect, equal opportunities, and equal rights" (1995, 10-1) and that "it is essential that we disabled people help to design, and take the lead in enablement programmes that do not try to normalise us into an unjust society, but rather empower us to become leaders in the struggle for transformation" $(1995,13)$. O'Keefe $(2007,150)$, therefore, states that a further important process measure in improving accessibility would be "an obligation to consult people with disabilities themselves in prioritizing investments to promote access, and in monitoring access outcomes". This toolkit enables both. 


\section{Permanent Monitoring and Effective Action for Eliminating Barriers in the Built Environment}

McDonald and Cooper (2009) indicate that many implementations of project practices have failed after the projects were finished. The authors state that the reason for this is because no mechanism was established during the project that would allow effective continuous monitoring of the implementation. That is the key reason why meeting the requirements for an accessible built environment in practice is taking place so slowly. This, of course, requires creating an appropriate and efficient system for processing and handling information about the accessibility of the built environment gathered through the web forum. At the same time, it is vital to point out that the Convention on Rights of Persons with Disabilities (United Nations, 2006) has already entered into force and includes the following requirements:

- “To develop, promulgate and monitor implementation of minimum national standards and guidelines for the accessibility of public facilities and services" (United Nations, 2006, 9);

- "In order to prevent the occurrence of all forms of exploitation, violence and abuse, State Parties shall ensure that all facilities and programmes designed to serve persons with disabilities are effectively monitored" (United Nations, 2006, 12);

- "State Parties shall, in accordance with their legal and administrative systems, maintain, strengthen, designate or establish within the State Party, a framework, including one or more independent mechanisms, as appropriate, to promote, protect and monitor implementation of the Convention" (United Nations, 2006, 25);

- "Civil society, in particular persons with disabilities and their representative organizations, shall be involved and participate fully in the monitoring process" (United Nations, 2006, 25).

According to O'Keefe (2007) only effective monitoring enables effective action because it allows for clear sanctions in the case of failure to comply with accessibility standards and administrative clarity on official accountability in cases of failure to comply. For this purpose, a monitoring service is to be created (the idea is to employ a person with a disability) as a part of the toolkit that will perform the initial processing of the information obtained (Figure 15).

The operator of the monitoring system should first respond to the initiative provided through the web forum. In the next phase an inquiry about the reported barrier should be made. If it turns out that the reported barrier really exists, the owner/manager of the particular facility with the reported barrier is notified. At the same time, an urgent effort will be made for further field investigation. An effective effort is guaranteed because the inspection-list criteria for determining accessibility take into account all relevant legal requirements and current standards. As such, the inspection list effectively verifies conformity with regulations, which effectively makes it a suitable instrument for conducting technical inspections of facilities. This means that appropriate action can be taken by experts from the responsible national authority if the instrument is officially recognised as such and (pre)-field investigations by assessors (see Figure 15) will no longer be necessary. This would simplify the management and system structure presented for monitoring accessibility in the built environment 


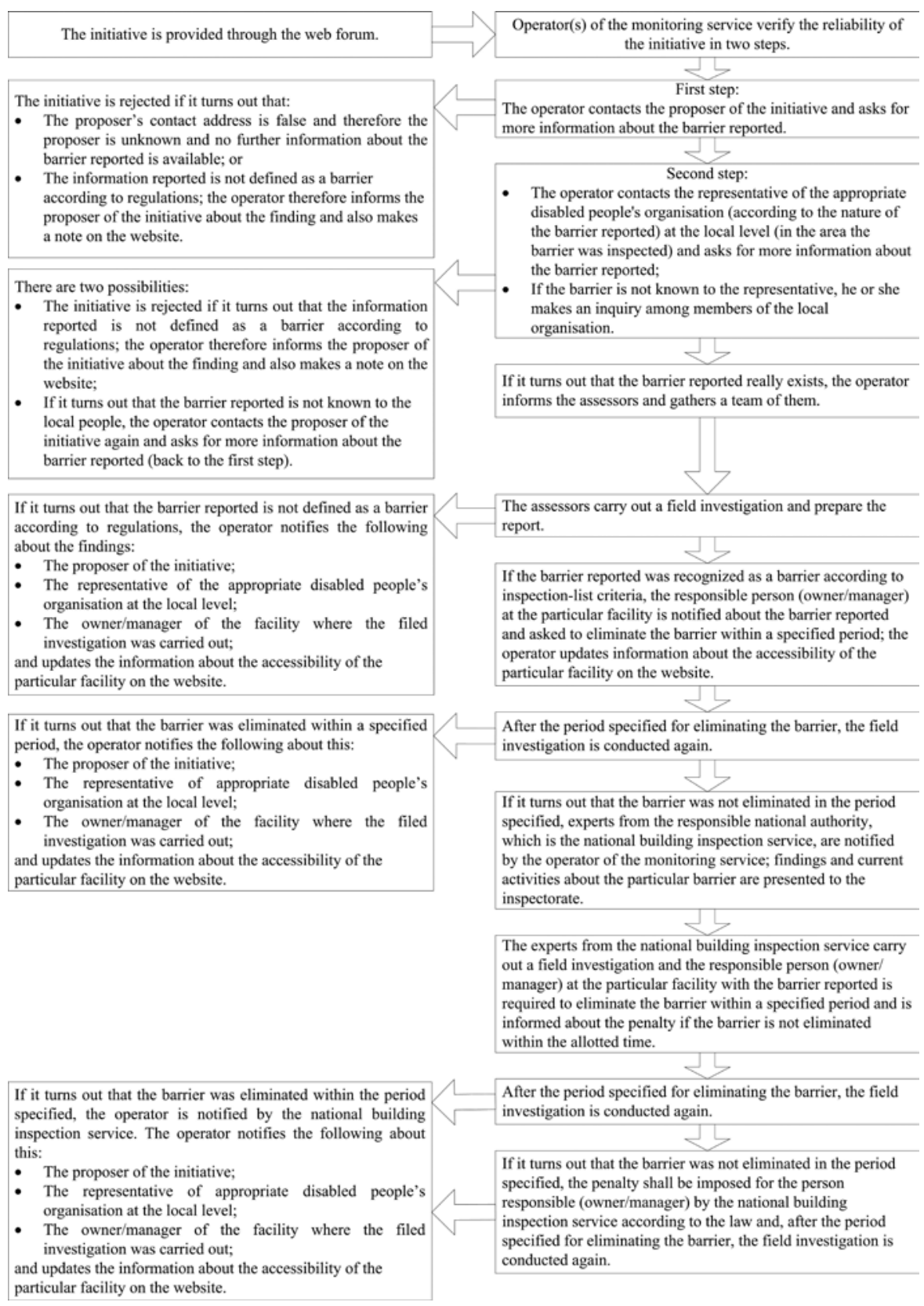

for monitoring accessibility in the built environment. and also accelerate elimination of existing barriers. In addition, the managers of the various public facilities will be able to commission an examination of the accessibility of their facilities by using the assessment list developed. Because the inspection list can considerably facilitate their access to information on the accessibility of public facilities, this represents a valuable innovation for building inspection services. The application of the toolkit for these purposes would, of course, require cooperation between the building inspection service and the toolkit operator. Seminars, workshops and training sessions are also planned to educate people that will become new assessors of the accessibility of the built environment. More assessors distributed in all areas/regions in the country also means faster responses to public initiatives, and more effective action and stricter monitoring. In the future the assessors could also become official experts 
in evaluating the accessibility of the built environment, licensed by the responsible national authority.

\section{CONCLUSION}

As presented in this article, the rights of people with disabilities to an accessible built environment are guaranteed by numerous documents. Consistent compliance with the provisions of the relevant laws and regulations is a precondition for ensuring an accessible built environment for people with disabilities. However, it was found that very little has been done so far to transfer these rules from paper to practice and therefore barrier-free access to the built environment is still not ensured. These findings were a motivation to start searching for new mechanisms to ensure effective realisation of the rights of people with disabilities to an accessible built environment. The toolkit developed and presented in the article is such a mechanism that enables a shift from paper declarations to a real action. It provides a new and more efficient mechanism in the effort to remove (and hopefully eventually completely eradicate) the various barriers that hinder people with disabilities from fully participating in society, allowing them to contribute to general economic development and improve their own wellbeing. Because the toolkit ensures unlimited and user-friendly access to information on accessibility, public participation for providing accessibility, and permanent monitoring and effective action for eliminating barriers in the built environment, it represents a comprehensive instrument that will offer policy-makers greater effectiveness in implementing policies for guaranteeing barrier free-access to the built environment.

On the other hand, this toolkit, even though it has been prepared, will not really come to life and serve to its purpose without successful implementation. This requires the active participation of various government institutions responsible for people with disabilities. This means that specific government departments are responsible for providing the necessary basic support for the operation of the toolkit; namely, (1) the toolkit should become an official instrument for indicating the status of accessibility in the built environment in the country and monitoring and assessing this status, and (2) it should be ensured that the relevant planning and building regulations are fully conformed with. Regarding the second issue, especially crucial are sanctions, which are usually not required in legislation along with measures. However, if they exist, they are often ignored because no sanction ignoring the application of sanctions is prescribed. Without this missing chain in legislation, the toolkit has no power to make changes because the experts conducting field inspections and monitoring spatial developments have no legal right to enforce the implementation of recommended actions and they also do not feel obligated to apply sanctions. In any case, when this deficiency is resolved, the toolkit will also serve its purpose after its implementation.

Another important characteristic of the toolkit is its potential transferability because the website, web forum and monitoring service are (with some specific adjustments) solutions that have the capacity to be replicated in other countries. Despite its complexity, the inspection list can also be transferred, with some adaptations. Namely, the inspection list is the principle instrument for assessing the accessibility of facilities. It therefore requires a preliminary review of all regulations concerning barrier-free access in a particular country. As such, it must be prepared 
with great sensitivity and accuracy. It should be ensured that all the vital requirements provided by laws, regulations and standards are covered.

It is certain that the toolkit will ensure stronger coordination between various institutions in the public sector. In this respect, the toolkit represents an additional advantage; that is, it simplifies the building inspectorate's work, increasing its efficiency in ensuring compliance with regulations. On the other hand, the toolkit also ensures greater engagement between public and non-public actors as well as the mobilisation of various actors at various levels because the toolkit can be used by everyone, not only by people with disabilities. Modern society is based on diversity, and therefore accessibility to the built environment is increasingly a concern for everybody, and not only for a minority with special needs. Everyone experiences barriers in the built environment (e.g., if the pavement is too high for a pram or a wheelchair, or if the doors are too narrow for a wheelchair, too heavy for a child or an older person, or they cannot even be found because the contrasts are too weak or attention fields are missing, the signage is inadequate, over-complex or confusing, etc). The toolkit therefore has much wider function and usability in society than can be imagined.

The development of the toolkit is clearly a significant step towards the practical realisation of the various commitments on the accessible built environment for people with disabilities that have, over the last decades, continued to remain resolutions, declarations, directives and action programmes on paper without effective implementation. It is certain that the toolkit will be accepted by people with disabilities and the general public because it was initiated in response to a pressing need of society; that is, developed at the initiative of people with disabilities.

\section{BIBLIOGRAPHY}

ARNSTEIN, S. R. (1969) A ladder of citizen participation, Journal of The American Institute of Planners (35) 216-24.

CALOUSTE GULBENKIAN FOUNDATION (1973) Current issues in community work, Routledge \& Kegan Paul, London.

COEFFIC, F. ed. (2010) Technical solutions for the accessibility of web sites: A current preoccupation for the disabled persons, The International eHealth, Telemedicine and Health ICT forum for Education, Networking and Business, Luxembourg.

COMMISSION OF THE EUROPEAN COMMUNITIES (1981) The social integration of disabled people - a framework for the development of community action, $\operatorname{COM}(81) 633$ Final, Brussels.

COMMISSION OF THE EUROPEAN COMMUNITIES (1997) Communication of the Commission of 30 July 1996 on equality of opportunity for people with disabilities: A New European Community Disability Strategy, COM (96) 406 final, Brussels.

COMMISSION OF THE EUROPEAN COMMUNITIES (2000) Towards a barrier free Europe for people with disabilities, COM(2000) 284 Final, Brussels.

COMMISSION OF THE EUROPEAN COMMUNITIES (2003) Equal Opportunities for people with disabilities: a European action plan, COM (2003) 650 Final, Brussells. 
COUNCIL OF THE EUROPEAN UNION (1997) Resolution of the Council and of the Representatives of the Governments of the Member States meeting within the Council of 20 December 1996 on equality of opportunity for people with disabilities, Official Journal C 12, 13, Brussels.

DEWSBURY, G.M. ed. (2004) Depending on digital design: extending inclusivity. Housing Studies (19) 811-25.

EUROPEAN COMMISSION (2010) European Disability Strategy 2010-2020 frequently asked questions, MEMO/10/578, Brussels.

EUROPEAN COMMISSION (2010) European disability strategy 2010-2020: a renewed commitment to a barrier-free Europe, $\operatorname{COM(2010)~} 636$ final, Brussells.

ERKILIÇ, M. (2011) Conceptual challenges between universal design and disability in relation to the body, impairment, and the environment where does the issue of disability stand in the philosophy of UD?, METU JFA (28) 181-203.

GARCÉS, J. ed. (2007) Free movements and equal opportunities for all (LivingAll). Compilation and classification of the national policies and action plans in Europe, LivingAll national initiatives report, Polibienestar, Valencia.

GERRY, R. (2002) Can mainstreaming save EU social policy? The cases of gender, disability, and elderly policy, European economic and political issues, volume 7, ed. F. Columbus, New York, Nova Science Publishers; 66-87.

GOODALL, B., POTTINGER, K.G. (2010) Promoting inclusive access to the built environment, CEM Occasional Paper, College of Estate Management, Reading.

HANSON, L. (1981) Designing with Care: A guide to Adaptation of the built Environment for Disabled People, Swedish International Development Authority and United Nations, New York.

HENRY, S. L. (2006) Understanding web accessibility, Web accessibility: Web standards and regulatory compliance, ed. R. Ruter, Apress, San Francisco; 7-31.

IMRIE, R., HALL, P. (2001) Inclusive design: designing and developing accessible environment, Spon Press, New York.

JONES, S. R (1981) Accessibility measures: a literature review, Transport and road research laboratory, Berkshire.

MACE, R. (1998) Universal design in housing. Assistive Technology (10) 21-8.

MACE, R., HARDIE, G., PLACE, J. (1991) Toward universal design, Design intervention. Toward a more humane architecture, eds. W. Preiser, J. Vischer, E. White, Van Nostrand Reinold, New York; 155-75.

McDONALD, S., COOPER, B. (2009) Implementation success or failure, Project Management (34) 12-28.

MEHRA, B., MERKEL, C., PETERSON BISHOP, A. (2004) The Internet for empowerment of minority and marginalized users, New Media $\mathcal{E}$ Society (6) 781-802.

MILNER, J., MADIGAN, R. (2004) Regulation and innovation: rethinking inclusive housing design. Housing Studies (19) 727-44. 
MOSETI, Y. (2010) Public participation for sustainable development in local cities. Paper was presented at the 46th ISOCARP Congress, Typescript, Kenya.

O'KEEFE, P. (2007) People with disabilities in India: From commitments to outcomes, World Bank, Washington DC.

REMAGNINO, P., SHAPIO, D. (2007) Artificial intelligence methodes for ambient intelligence. Computational Intelligence (23) 393-4.

SENDI, R., KERBLER, B. (2009) Disabled people and accessibility: How successful is Slovenia in the elimination and prevention of builtenvironment and communication barriers? Urbani izziv (20) 123-40.

THATCHER, J. ed. (2003) Constructing accessible web sites, Apress, San Francisco.

UNITED NATIONS (1982) World Programme of Action concerning Disabled Persons, A/RES/37/52, New York.

UNITED NATIONS (1993) Standard rules on the equalization of opportunities for persons with disabilities, A/RES/48/96, New York.

UNITED NATIONS (2006) Convention on the rights of the disabled, A/ RES/61/106, New York.

WELCH, P. ed. (1995) Strategies for teaching universal design, Adaptive Environments Centre, Boston.

WERNER, D. (1995) Strengthening the role of disabled people in community based rehabilitation programmes, Innovations in developing countries for people with disabilities, eds. B. O'Toole, R. McConkey, Lisieux Hall, Chorley.

WORLD HEALTH ORGANIZATION (2011) World report on disability, Geneva.

\section{ACKNOWLEDGEMENTS}

The research was supported by the Slovenian Research Agency and the Ministry of Labour, Family and Social Affairs. Special thanks goes also to the Disabled Students Association of Slovenia, especially to its members, who participated in the field investigation. The author would like to thank the reviewer for his/her exceptionally relevant comments and suggestions.

Alındı: 19.04.2012; Son Metin: 17.07.2012

Anahtar sözcükler: engellilik, engelli bireyler, yapılı çevre, yapılı çevredeki engeller, engelsiz erişim, araç seti.

\section{ENGELLILERIN YAPILI ÇEVREDE KARŞILAŞTIKLARI ENGELLERI SAPTAMAK VE GIDERMEK İÇIN BİR ARAÇ SETİ: SLOVENYA ÖRNEĞİ, AVRUPA}

Erişilebilir yapılı çevre, engelli bireylerin en önemli haklarından birisidir. $\mathrm{Bu}$, onların topluma eşit ve etkin katılımlarını sağlar. Bu nedenle, yapılı çevrede bulunan tüm ayrımcı unsurları gidermek ve çeşitli engelleri ve diğer sınırlamaları ortadan kaldırmak amacıyla birçok yasa ve yönetmelik kabul edilmiştir. Bu makale, yazarın geçmişte yürüttüğü, şimdiye kadar bu amaçları uygulamaya geçirmek konusunda çok az şey yapıldığını ve engellilerin ulaşılabilir yapılı çevreye katılım hakkının hala sağlanamadığını gösteren çalışmalarının bulgularından gelişmiştir. Bu nedenlerden dolayı, alan çalışması temelinde yeni bir araç seti 
(toolkit) geliştirilmiştir; bu makale, önerilen araç setinin kanunların uygulanması aşamasında karar vericilerin engellilerin yapılı çevreye tam olarak erişebilmelerini garanti etmek konusundaki etkinliklerine katk1 sağlayabilecek kapsamlı bir araç olduğunu göstermektedir. Araç setinin gelişimi, yapılı çevrenin engelliler için erişebilir olması konusundaki birçok sorumlulukların pratikte gerçekleşmesinde önemli bir aşamadır. Bu aracın en temel özelliği, erişebilirlik hakkındaki bilgiye kısıtlamasız ve kullanıcı dostu (user-friendly) bir yaklaşımla ulaşımı, erişebilirliği sağlamak için kamusal katılımı ve yapılı çevrede bulunan engelleri kaldırmak için sürekli izleme ve aktif bir eylem alanı sağlamasıdır. Diğer taraftan, bu araç setinin en değerli yanı onun farklı toplumlar için dönüştürülebilir ve geniş bir uygulama ağına sahip olmasıdır.

BOŠTJAN KERBLER; PhD.

Has PhD in social geography. Is a researcher at the Urban Planning Institute of the Republic of Slovenia. His research deals with spatial planning and housing for people with disabilities and older people. Is the editor of the international scholarly journal Urbani Izziv ("Urban Challenge"). bostjan.kerbler@uirs.si 